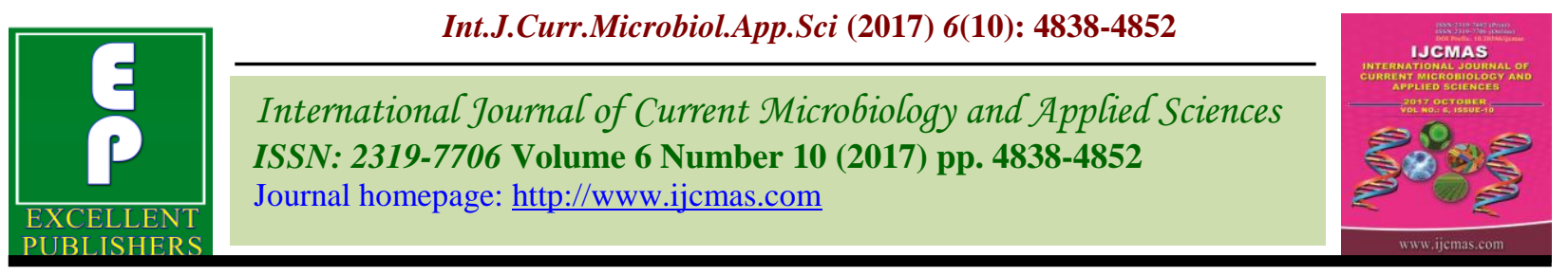

Original Research Article

https://doi.org/10.20546/ijcmas.2017.610.452

\title{
Nutritional, Microbiological and Rheological Characteristics of Porridges Prepared from Infant Flours Based on Germinated and Fermented Cereals Fortified with Soybean
}

\author{
Sandrine E. Kouton', Waliou Amoussa-Hounkpatin ${ }^{2}$, \\ Venerande Y. Ballogou ${ }^{1}$ and Mohamed M. Soumanou ${ }^{1 *}$ \\ ${ }^{1}$ Unité de Recherche en Génie Enzymatique et al.,imentaire/École Polytechnique d'Abomey \\ Calavi (EPAC)/ Université d'Abomey-Calavi (UAC), 01 BP 2009 Cotonou, Bénin \\ ${ }^{2}$ Département de Nutrition et Sciences Alimentaires/Faculté des Sciences Agronomiques (FSA)/ \\ Université d'Abomey-Calavi (UAC) 01 BP 526 Cotonou, Bénin \\ *Corresponding author
}

\section{A B S T R A C T}

\begin{tabular}{|c|}
\hline Keywords \\
\hline $\begin{array}{l}\text { Complementary } \\
\text { food, Infant, } \\
\text { Malnutrition, } \\
\text { Process, } \\
\text { Germination, } \\
\text { Fermentation. }\end{array}$ \\
\hline Article Info \\
\hline $\begin{array}{l}\text { Accepted: } \\
\text { 29 September } 2017 \\
\text { Available Online: } \\
10 \text { October } 2017\end{array}$ \\
\hline
\end{tabular}

The complementary feeding was a critical period for the child's growth. The germination and fermentation processes were used to improve the properties of infant flours-based maize, sorghum and soybeans. The physico-chemical and the nutritional composition of the porridges prepared from these infant flours were d etermined. The incorporation of roasted soybean flour, sugar and 'baobab" pulp in the traditional germinated infant flour (containing germinated maize and sorghum flours in rate 50/50) improved the taste of porridge and the dry matter increasing from $25.31 \%$ to $31.23 \%$. The energy value increased from $101.24 \%$ to $124.92 \mathrm{kcal}$ and protein levels from $10.20 \%$ to $16.65 \%$.In the fermentation process, the use of 'Mawè' (dehulled and fermented maize dough) andthe incorporation of roasted soybean flour, germinated maize flour, sugar and "'baobab" pulp in traditional infant flour (containing "Mawè" flour, roasted sorghum flour and "Mawè" dough in rate 50/46/04) improved the dry matter to increasing from $22,98 \%$ to $30.09 \%$. Consequently, the energy value increased from $91.92 \mathrm{kcal}$ to $120.36 \mathrm{kcal}$ and the protein levels from $2.73 \%$ to $15.32 \%$.These fermented and germinated infant flours allowed to prepare infants porridges according to the standards which could contribute to the fighting of child' malnutrition.

\section{Introduction}

From the age of 6 months, breast milk is no longer sufficient to meet infant nutritional needs, therefore consumption of other foods is necessary to complement what breast milk provides, according to WHO recommendations (WHO, 2003). Adoption of recommended complementary feeding practices and access to the appropriate quality and quantity foods are essential components of optimal nutrition for infants and young children (Songré-Ouattara et al., 2016). Indeed, complementary feeding period is the time when malnutrition starts in many infant and it significantly contributes to the high prevalence of malnutrition in children under 5 years of age worldwide (WHO, 2012). Many factors contribute to the vulnerability of children during the complementary feeding 
period (Victora et al., 2016). The complementary foods are often characterised by low nutritional quality and given to infant in insufficient amounts. When given too early or too frequently, they are likely to displace breast milk (Dolan et al., 2015). In developing countries, mothers most often use as complementary foods, traditional porridge cereal flour or cassava (Manihotesculenta), starch-rich products (Trèche, 2002) which are poor in protein. However, these products do not sustain any preliminary enzymatic treatment and come own in the preparation of porridge without the addition of protein-rich foods such as legumes or milk (Tshite et al., 2015). These are consistence, heavy, viscous, and indigestible porridges for children, due to the starch which has ability to swell during cooking. Mothers are constraint to add water in the preparation making them much more fluid porridge and easy to digest. This practice reduces the dry matter, by the way it influences the energy value of porridge (Trèche, 2002). As they have a small volume of stomach $(30 \mathrm{ml} / \mathrm{kg}$ body weigh),children are obliged to consume very little quantity of porridge that seems to be satiated but lacks of essential nutrients (Salle, 2009).Traditional maize-based porridge given to children has a very low energy value. Besides,36- 60 cal $/ 100 \mathrm{ml}$ for porridge with mill et and sorghum were used in Burkina Faso, 44 - 64 cal / 100 $\mathrm{ml}$ in Gabon and $60 \mathrm{cal} / 100 \mathrm{ml}$ in Congo with low micronutrient densities (Salle, 2009).

In Benin, complementary feeding practices are not optimal. Complementary foods introduced by the mothers are mostly simple maize porridge and / or whether or not fermented sorghum porridge obtained from recycled maize dough. Porridge is slightly enriched with protein materials and daily distribution frequency is low (Atègbo, 1993; Kouton et al., 2017). Poor feeding practices and shortfall in food intake are the most important direct factors responsible of malnutrition and illness among children in Benin (Amoussa Hounkpatin, 2011). These practices, which are the use of poor quality complementary foods and inappropriate conduct of complementary feeding practices, partly explain the prevalence of $34 \%$ of stunting observed in Benin preschool children (INSAE, 2015). The economic consequences of chronic malnutrition represent losses of 11 percent of gross domestic product (GDP) each year in Africa and Asia, while the prevention of malnutrition offers $\$ 16$ of returns on investment for every $\$ 1$ spent (GNR, 2016).

Energy value is a very important factor in young children feeding and represents the calories in a given volume of porridge (Ponka et al., 2016). Indeed, when the volume of food consumed is low energy value, the child suffers from a double deficit in energy and protein ingested. It is then necessary to propose to mothers, the high energy dense foods and adequately fluid consistency porridges which will cover infants' needs. WHO and UNICEF (2003) recommend that porridges must have dry matter approaching $30 \%$ at least and energy value approaching $120 \mathrm{kcal} / 100 \mathrm{ml}$ and more so taking two ratio of porridges a day could cover daily energy needs. Researchers have recognized the need to increase the energy value of complementary food of young children in order to prepare high energy porridge that could cover all the nutritional and energy needs for African young children (Zannoutchoco et al., 2011; Amoin et al., 2015).

In order to reach these goals, it is important to develop process which can help to increase the energy value of infant flours used as complementary foods. So, improving the energy value, the fluidity of local porridge and mineral bioavailability are necessary. The starch flours must sustain technological treatments that cause breaking of the glycosidic bonds in order to reduce the 
swelling ratio and increase their fluidity and energy value while cooking.

These treatments are between other fermentation and germination (Kayodé et al.,2012; Amoin et al., 2015).Fermentation is one of the oldest and most economical methods of producing and preserving foods that improves the organoleptic properties of foods by developing a variety in flavours (Hounhouigan et al., 1993; Vieira-Dalodé et al., 2007). Another advantage of fermentation is to increase the nutritional value and the digestibility of foods (Kayodé et al., 2012). In west-Africa and especially in Benin, many foods are obtained by fermentation such as, "Mawè" which is a sour dough made from maize (Hounhouigan et al., 1993). "Mawè" is dehulled fermented maize dough used to prepare many dishes including gels ("akassa", cooked bread ("ablo") and granulated porridge "Aklui" and "Akluiyonou").

The incorporation of germinated cereals flour makes it possible to prepare sufficiently fluid porridge with high concentrations of dry matter and energy while reducing the quantity of water (Anigo et al., 2010; Zannou-tchoco et al., 2011; Sanoussi et al., 2013). Malting of cereals is a processing procedure traditionally used in many African countries for the manufacture of alcoholic drinks, juices, and malted drinks (Kayodé et al., 2006). The malting of cereal seeds also has the advantage of reducing the phytate content (Traoré et al., 2004), which should improve the bioavailability of some essential minerals (iron, calcium, zinc) for the young children (Amoin et al., 2015).

The objective of this study is to compare the biochemical, rheological, microbiological, and nutritional characteristics of porridges prepared with local products (maize, sorghum and soybeans) using fermentation and germination technologies.

\section{Materials and Methods}

The raw material is consisted of two cereals such as: maize (Zea mays), red sorghum (Sorghum bicolor), and grains of soybean (Glycine max; yellow grains). Soybean, red sorghum, and maize grains, the sugar and baobab pulp (Adansonia digitata) were obtained from local market located in southern Benin. For fermented infant flour, the ferment used is "Mawè", a sour dough fermented made from maize. The "Mawè" production diagram was described by Hounhouigan et al., (1993).

\section{Infant flours preparation and formulation}

\section{Infant flours preparation}

Grains of cereals were cleaned and washed in water before the production of the infant flours. The grains of maize and red sorghum were malted as described by Traoré et al., (2004). For the preparation of infant germinated flour, grains of maize and sorghum are soaked during $24 \mathrm{~h}$ and are spread out on cloth humidified for 3 days. Malted seeds are dried at $65^{\circ} \mathrm{C}$, sorted out, degermed, and crushed. After sieving from $500 \mu \mathrm{m}$ size sieves, malted maize and sorghum flours were obtained (Figure 1). The grains of soybean are roasted and crushed. Soybean roasted flour, maize and red sorghum malted flours, baobab pulp and sugar are mixed in different proportions. For the Infant fermented flour, sorghum, and soybeans were roasted, crushed and sieved separately with a sieve of $500 \mu \mathrm{m}$ diameter. The fermented infant flour has been prepared by mixing, in varied proportions, the previous flours and "Mawè", sugar and baobab pulp in $100 \mathrm{ml}$ of water. The mixture was placed in poly ethylene bag at room temperature to simulate the storage conditions in developing countries. After having heaped the dough to allow the fermentation under anaerobic 
conditions, the bag was sealed and placed in a plastic container. The fermentation lasted 72 hours (Brou, 2000).

\section{Infant flours formulation}

Infant germinated flours were processed by mixing maize and sorghum germinated flours in $50 \%-50 \%$ ratio (Fg1: traditional porridge). For the optimized and fortified formulation (Fg2 and Fg3), maize and sorghum germinated flours, soybean roasted flour, sugar and "baobab" pulpare mixed in different ratio (Table 1).

Infant fermented flours were processed by mixing "Mawè", sorghum roasted flour and "Mawè" washed in 50\%-46\%-04\% ratio ( $\mathrm{F} 1$ : traditional porridge). For the optimized and fortified formulation (F2 and F3), "Mawè", sorghum and soybean roasted flours, "Mawè" washed, sugar and "baobab" pulp are mixed in different ratio (Table 2). The infant flours obtained were then stored in sealed poly ethylene bags.

The mixture optimizations and fortified were performed for the infant flours using computer program (optimize mixture design) through Minitab 14 software application to calculate the proportions of ingredients needed for a protein level in the range of 14.9 $\mathrm{g}$ to $16 \mathrm{~g} / 100 \mathrm{~g}$, and a fat content in the range of $7 \mathrm{~g}$ to $9 \mathrm{~g} / 100 \mathrm{~g}$, as specified by FAO and WHO Commission (2006) recommendations for infant complementary food for older infants and young children.

Physico-chemical, nutritional and microbiological analysis of the infant flours

The physico-chemical compositions and caloric energy value assessment of infant flours were determined using recommended methods. The samples were analysed for dry matter, crude protein, crude fat, ash content,
$\mathrm{pH}$ and titratable acidity. Protein, fat, and ash contents of the samples were determined following AOAC (1990) and the process described by Soro et al., (2013). Total available carbohydrate was calculated as $100 \%$ minus the sum of moisture, protein, fat and ash contents obtained as described above. Energy Value (EV) was calculated according to equation of Atwater and Benedict (1902). $E V=(9 \times$ Fat $(\%)+4 \times$ Proteins $(\%)+4 x$ Carbohydrates (\%)). The fluidity of porridge is the flow speed measured with a Bostwick Consistometer according to the method of Zannou-tchoko et al., (2011). Moreover, Phytic acid was determined by the method of Anigo et al., (2010), tannin by method of Umaru et al., (2007), and phenolic compound by method of Soro et al., 2013. Properties of Swelling and solubility of infant flours have been determined by gravimetric analysis in the protocol of $\mathrm{Li}$ and Corke (1999) reported by Soro et al., (2013).

Mineral element (Fe, $\mathrm{Ca}, \mathrm{Zn}$ and $\mathrm{Mg}$ ) concentrations were obtained using Atomic Absorption Spectrophotometer. Microbiological analysis was performed using the method described by Guiraud and Galzy (1980) reported by Sanoussi et al., 2013. Micro-organisms research included total aerobies, yeasts and molds, faecal coliforms, and Escherichia coli bacteria. All the results were carried out in triplicates.

\section{Statistical analysis}

The $\mathrm{t}$ Test of Students, Newman Keuls and ANOVA procedures in Statistica 7.1 were used to perform descriptive analysis and compare the means of triplicate measurements of physico-chemical, nutritional, and rheological parameters. Let's notify that the means were considered to be significantly different when $\mathrm{p}<0.05$. The least significant difference test was used to separate the means when the difference was significant. 


\section{Results and Discussion}

\section{Characteristics of porridges prepared by germination process}

The characteristics of porridges were evaluated by the determination of fluidity, dry matter, protein, and energy value (Table 3). For $100 \mathrm{~g}$ of the mixture, Fg1 (containing germinated maize and sorghum germinated in ratio $50 / 50$ ) has $25.31 \%$ dry matter, the fluidity was $180 \mathrm{~mm} / 30 \mathrm{sec}$, protein ratio was $10.20 \%$, and energy value was 101.24 kcal. However, these dry matter and protein levels are less than $30 \%$ for dry matter and $15 \%$ for protein, values recommended by the WHO for infant porridges. These two parameters have been improved by the incorporation of roasted soybean flour and baobab pulp (formulation Fg2).

The porridge resulting from this formulation has a sufficient protein content of $16.65 \%$ with a dry matter content of $28.57 \%$ which remains insufficient $(<30 \%)$. The fluidity of porridge $\mathrm{Fg} 2$ was $160 \mathrm{~mm} / 30 \mathrm{sec}$ and the energy value was $114.28 \mathrm{kcal}$.

At this step, the improvement of dry matter was made by addition of sugar. So, with an addition of $5 \%$ of sugar in formulation $\mathrm{Fg} 2$, formulation $\mathrm{Fg} 3$ was obtained. The sugar improved the taste and the dry matter was increased from $28.57 \%$ to $31.23 \%$.

Energy value also increases from $114.28 \mathrm{kcal}$ to $124.92 \mathrm{kcal}$ and fluidity changed from 160 to $155 \mathrm{~mm} / 30 \mathrm{sec}$. However, the protein level remains at $16.65 \%$. Among all formulations studied, only $\mathrm{Fg} 3$ flour containing 30\% germinated maize flour, $30 \%$ germinated sorghum flour, $30 \%$ germinated soybeans flour, and 5\% sugar allowed to prepare a porridge having $124.92 \mathrm{kcal}$ energy value and that could cover the infant energy requirements $(120 \mathrm{kcal})$.

\section{Characteristics of porridges prepared by fermentation process}

The characteristics of porridges according to fermentation process were listed in Table 4. For $100 \mathrm{~g}$ of the mixture, formulation $\mathrm{F} 1$ (containing "Mawè" flour, roasted sorghum flour, and "Mawè" dough in ratio 50/46/04) has $22.98 \%$ of dry matter, $91 \mathrm{~mm} / 30 \mathrm{sec}$ of fluidity, $2.73 \%$ of protein ratio, and 91.92 kcal about energy value. We notice that, dry matter and protein contents are respectively less than $30 \%$ and $15 \%$, according to the recommendation of WHO for infant porridges. These two parameters have been improved by the incorporation of roasted soybean flour, baobab pulp, and sugar (formulation F2). The resulting porridge from this formulation has a sufficient protein content $(15.25 \%)$ but dry matter $(25.24 \%)$ remains insufficient. The fluidity of formulation F2 was $95 \mathrm{~mm} / 30 \mathrm{sec}$ and energy value was $100.96 \mathrm{kcal}$ (< $120 \mathrm{kcal})$. The improvement of dry matter and energy value was made by the incorporation of $04 \%$ of germinated maize flour and 7\% of "Mawè" into the F2 formulation. In F3 formulation, there are dry matter contents of $30.09 \%$, energy value of $120.36 \mathrm{kcal}$, protein ratio of $15.32 \%$, and a fluidity of $110 \mathrm{~mm} / \mathrm{sec}$. Among the tree studied formulations, only F3 porridge containing 27\% of "Mawè", 26\% roasted sorghum flour, $26 \%$ roasted soybeans flour, $4 \%$ of germinated maize flour, $7 \%$ of ferment ("Mawè" dough), $5 \%$ of sugar, and $5 \%$ of baobab pulp allowed to prepare a porridge having $120.36 \mathrm{kcal}$ energy value in accordance with WHO (2003) recommendations and could cover the infant energy requirements.

\section{Physico-chemical characteristics of germinated and fermented infant flours}

These characteristics of germinated and fermented infant flours, were summarized in 
Table 5. Germinated (Fg3) and fermented (F3) infant flours revealed, apart from carbohydrates, protein, fat, and ash which were statistically different $(\mathrm{P}<0.05)$ to the rates of each nutrient taken independently. The germinated infant flour Fg3 contains $96.85 \pm 0.02 \%$ dry matter, $16.65 \pm 0.06 \%$ protein, and $8.27 \pm 0.03 \%$ fats, while fermented compound infant flour (F3) contains $92.62 \pm 0.03 \%$ dry matter, $15.32 \pm$ $0.10 \%$ protein, and $6.2 \pm 0.01 \%$ fats. The carbohydrates content was $68.68 \pm 0.5 \%$ in germinated mixed flour and $68,25 \pm 0.2 \%$ in fermented flour. The ash content was $3.25 \pm$ $0.5 \%$ and $2.85 \pm 0.08 \%$ respectively in the germinated mixed flour and the fermented compound flour. The dry matter, protein, Fats, and ash content of the $\mathrm{Fg} 3$ flour are higher than the fermented infant flour F3 but still in accordance with the complementary food standard recommended by $\mathrm{FAO} / \mathrm{WHO}$ (2006). Fermented infant flour (F3) has a lipid content (6.2\%) and ash content (2.85\%) which are lower than the recommendations of the FAO / WHO (2006).

Levels of anti-nutrient in the formulated complementary foods revealed that F2 (5.34 \pm $0.03 \mathrm{mg} / 100 \mathrm{~g}), \mathrm{Fg} 3(26.77 \pm 0.06 \mathrm{mg} / 100 \mathrm{~g})$ and $\mathrm{Fg} 3 \quad(53.54 \quad \pm \quad 0.02 \mathrm{mg} / 100 \mathrm{~g})$ had significantly higher $(\mathrm{p}<0.05)$ phytates, tannin and polyphenol compounds concentrations respectively. Phenolic compounds and the tannin content of infant flours differ significantly $(\mathrm{p}<0.05)$. This result indicates that the phenolic content of germinated infant flours was higher than the one of the fermented infant flours $(\mathrm{p}<0.05)$. Phenolic content of Fg3 (53.54 \pm 0.02 $\mathrm{mg} / 100 \mathrm{~g}$ ) germinated infant flour was higher than phenolic content of fermented infant flour F3 $(47.82 \pm 0.05 \mathrm{mg} / 100 \mathrm{~g})$. The tannin content of germinated infant flours was higher than fermented infant flour $(\mathrm{p}<0.05)$. The tannin content of Fg3 $(26.77 \pm 0.06 \mathrm{mg} / 100 \mathrm{~g})$ germinated infant flour was higher than that of the fermented infant flour F3 $(23.03 \pm 0.02$ $\mathrm{mg} / 100 \mathrm{~g}$ ). There was significant difference between the phytate contents of germinated and also in fermented infant flours. The phytate content of fermented infant flour were not significantly different and the values were $5.32 \pm 0.02 \mathrm{mg} / 100 \mathrm{~g} ; 5.33 \pm 0.02 \mathrm{mg} / 100 \mathrm{~g}$ and $5.34 \pm 0.03 \mathrm{mg} / 100 \mathrm{~g}$ respectively for $\mathrm{F} 1$, F3 and F2. The phytate contents of the germinated infant flour were not significantly different and the values were in Fg1 (3.2 \pm $0.01 \mathrm{mg} / 100 \mathrm{~g}), \mathrm{Fg} 2(3.3 \pm 0.01 \mathrm{mg} / 100 \mathrm{~g})$ and $\mathrm{Fg} 3(3.5 \pm 0.00 \mathrm{mg} / 100 \mathrm{~g})$. Phytate content in $\mathrm{Fg} 3(3.5 \pm 0.00 \mathrm{mg} / 100 \mathrm{~g})$ was lower than that of F3 $(5.33 \pm 0.02 \mathrm{mg} / 100 \mathrm{~g})$.

The functional properties and energies values of the fermented and germinated infant flours were presented in Table 6 . The energy values of infant flours were significantly different ( $p$ $<0.05$ ). The energy value of infant flours ranges from $375.12 \pm 0.60 \mathrm{kcal}$ to $415.75 \pm$ $2.61 \mathrm{kcal}$. The infant flour germinated $(\mathrm{Fg} 3)$ and fermented (F3) whose porridges characteristics (nutritional and rheological) were conform to the recommendation standard of FAO/WHO (2006), have energy value respectively of $415.75 \pm 2.61 \mathrm{kcal}$ and $390.08 \pm 1.51 \mathrm{kcal}$. The energy value of the germinated flour $\mathrm{Fg} 3$ was higher than the one of the fermented flour F3. The energy value of F3 fermented flour was lower than the recommended energy value (400 kcal) for complementary foods, while that of $\mathrm{Fg} 3$ germinated infant flour was conformed to the FAO/WHO Standard (2006). The solubility and swelling of fermented and germinated infant flours are significantly different $(p<0.05)$. The solubility indices (sugar released during the heating of the various flours) range from $12.26 \% \pm 0.25$ to $58.52 \%$ \pm 0.14 . The results indicate that infant flours obtained by the germination process have significantly higher solubility indices $(p<0.05)$ compare to the fermented infant flours. The solubility indices of the 
germinated and fermented flours decreased from traditional formulations to fortified formulations. According to the results, germinated infant flours released $\mathrm{Fg} 3$ $(46.49 \% \pm 0.21)$ were about four (04) times more soluble than the fermented flour F3 $(12.26 \% \pm 0.25)$.Swelling powers of germinated infant flours were significantly $(p<0.05)$ lower than those of fermented compound flours. The swelling values range from $6.03 \mathrm{ge} / \mathrm{g} \pm 0.12$ to $14.08 \mathrm{ge} / \mathrm{g} \pm 0.18$. The swelling powers of germinated and fermented flours decreased from traditional formulations to fortified formulations. The germinated infant flour Fg3 (6.03 ge/g \pm 0.12$)$ has a lower swelling power than the one of a fermented flour F3 (11.22ge/g \pm 0.28$)$. The titratable acidities of germinated infant flours were significantly lower than those of fermented infant flour and the $\mathrm{pH}$ of germinated infant flour was significantly higher than that of fermented infant flour. The titratable acidities values range from $0.13 \% \pm$ 0.05 to $2.45 \pm 0.1 \%$ eq lactic acid and the $\mathrm{pH}$ values range from $3.75 \pm 0.01$ to $6.12 \pm 0.04$.

\section{Microbiological analysis and mineral content of infant flours Fg3 and F3}

These analysesconcerned the infant flours germinated Fg3 and fermented F3. According to FAO and WHO recommendations (1994) related to the microbiological qualities of infant flours intended for cooking, the total number of total aerobes, yeasts and moulds, faecal coliforms, and Escherichia coli should be less than $10^{5}, 10^{3}, 10^{2}$ and $10 \mathrm{cfu} / \mathrm{g}$ respectively. Fermented infant flour F3 (3.95 $\pm 0.21 \log 10 \mathrm{cfu} / \mathrm{g}$ ) had significantly higher ( $\mathrm{p}$ $<0.05)$ total aerobic counts and significantly higher $(2.75 \pm 0.10 \log 10 \mathrm{cfu} / \mathrm{g})$ yeast and fungi counts. Infant flours Fg3 and F3 did not record any growth for faecal coliforms and Escherichia coli. Mineral contents of the germinated infant flour Fg3 were higher than the fermented infant flour (Table 8). Iron
(14.32 $\mathrm{mg})$, zinc (11.05 $\mathrm{mg})$, and magnesium $(88.27 \mathrm{mg})$ contents of germinated infant flour $\mathrm{Fg} 3$ were higher than the minimum value respectively of $8.5 \mathrm{mg}, 3.7 \mathrm{mg}$, and $48.7 \mathrm{mg} / 100 \mathrm{~g}$ recommended by FAO and WHO (2006) for complementary infant flours. The calcium content of germinated infant flour $\mathrm{Fg} 3$ (308.7 $\mathrm{mg}$ ) and fermented infant flour F3 (257.5 mg) of) were lower than the minimum value of $341.2 \mathrm{mg}$ recommended by FAO and WHO (2006).

The biochemical characteristics of the porridges prepared revealed that the dry matter content is inversely proportional to the fluidity (Tables 3 and 4). Indeed, the lower the dry matter of porridges is the lower the fluidity and energy value. For infants, poor protein and energy dense porridges will induce a significant weight reduction. In the germinated flour, the incorporation of roasted soybean flour, sugar, and "baobab" pulp improved the taste of the porridge and the dry matter increased from $25.31 \%$ to $31.23 \%$.

Energy value increased from $101.24 \%$ to $124.92 \mathrm{kcal}$, protein levels from $10.20 \%$ to $16.65 \%$, and fluidity varied from $180 \mathrm{~mm}$ to $155 \mathrm{~mm} / \mathrm{sec}$.Regarding fermented infant porridge, the incorporation of roasted soybean flour, germinated maize flour, and the "Mawè', sugar and "baobab" pulp improved the dry matter increasing from $22.98 \%$ to $30.09 \%$. Also energy value increased from $91.9 \mathrm{kcal}$ to $120.36 \mathrm{kcal}$ and protein levels from $2.73 \%$ to $15.32 \%$ while fluidity increased from 91 to $110 \mathrm{~mm} / 30 \mathrm{sec}$. The advantage of the incorporation of roasted soybean flour in the germinated and fermented infant flours was justified by the fact that it contains proteins good biological value especially amino acids as well as vitamins and minerals. The high lipid content of soybeans gives a good caloric value. In addition, the consumption of food sources of vegetable proteins (legumes) should be 
encouraged as they were locally available and inexpensive. The incorporation of roasted soybean flour decreased the fluidity of the porridges obtained from the germinated infant flours. These results were in lined with those of Soro et al., (2013) which showed that the incorporation of roasted soybean flour decrease the fluidity of the porridges.

Table.1 Infant flours formulation by germination process

\begin{tabular}{c|ccccc}
\hline \multicolumn{7}{c}{ Material (\%) } \\
\hline Infant flours & $\begin{array}{c}\text { Germinated maize } \\
\text { flour }\end{array}$ & $\begin{array}{c}\text { Germinated } \\
\text { sorghum flour }\end{array}$ & Roasted soybeans & Sugar & 'Baobab" \\
Fg1 & 50 & 50 & flour & 0 & 0 \\
Fg2 & 32 & 32 & 31 & 0 & 05 \\
Fg3 & 30 & 30 & 30 & 05 & 05 \\
\hline
\end{tabular}

Table.2 Infant flours formulation by fermentation process

\begin{tabular}{c|ccccccc}
\hline \multicolumn{2}{c}{ Material (\%) } \\
\hline $\begin{array}{c}\text { Infant } \\
\text { flours }\end{array}$ & $\begin{array}{c}\text { "Mawè' } \\
\text { 'flour }\end{array}$ & $\begin{array}{c}\text { Roasted } \\
\text { sorghum flour }\end{array}$ & $\begin{array}{c}\text { Roasted } \\
\text { soybeans } \\
\text { flour }\end{array}$ & $\begin{array}{c}\text { Germinated } \\
\text { maize flour }\end{array}$ & $\begin{array}{c}\text { Sugar } \\
\text { "'Baobab" } \\
\text { pulp }\end{array}$ & $\begin{array}{c}\text { Ferment: } \\
\text { "Mawè'”dough }\end{array}$ \\
F2 & 50 & 46 & 0 & 0 & 0 & 0 & 04 \\
F3 & 30 & 28 & 28 & 0 & 05 & 05 & 04 \\
\hline
\end{tabular}

Table.3 Physicochemical characteristics of porridges prepared by germination process

\begin{tabular}{c|ccccc}
\hline & \multicolumn{5}{|l}{ Characteristics of porridges } \\
\hline Porridges & Ratio $(\%)$ & $\begin{array}{c}\text { Fluidity } \\
(\mathrm{mm} / 30 \mathrm{sec})\end{array}$ & $\begin{array}{c}\text { Dry matter } \\
(\%)\end{array}$ & Protein $(\%)$ & $\begin{array}{c}\text { Energy } \\
\text { value }(\mathrm{kcal} / 100 \mathrm{ml})\end{array}$ \\
Fg1 & $50 \%-50 \%$ & $180 \pm 6$ & $25.31 \pm 0.11$ & $10.20 \pm 0.3$ & $101.24 \pm 1.6$ \\
Fg2 & $32 \%-32 \%-31 \%-0 \%-$ & $160 \pm 4$ & $28.57 \pm 1.3$ & $16.65 \pm 1.2$ & $114.28 \pm 2.3$ \\
& $05 \%$ & & & & \\
Fg3 & $32 \%-32 \%-31 \%-05 \%-$ & $155 \pm 3$ & $31.23 \pm 0.8$ & $16.65 \pm 1.2$ & $124.92 \pm 1.8$ \\
& $05 \%$ & & & & \\
\hline
\end{tabular}

Table.4 Physico-chemical characteristics of porridges prepared by fermentation process

\begin{tabular}{|c|c|c|c|c|c|c|}
\hline & \multicolumn{6}{|c|}{ Characteristics of porridges } \\
\hline Porridges & Ratio & $\begin{array}{c}\text { Ratio of } \\
\text { ferment } \\
(\%)\end{array}$ & $\begin{array}{c}\text { Fluidity } \\
(\mathrm{mm} / 30 \\
\text { sec) }\end{array}$ & $\begin{array}{c}\text { Dry } \\
\text { matter } \\
(\%)\end{array}$ & $\begin{array}{l}\text { Protein } \\
\quad(\%)\end{array}$ & $\begin{array}{l}\text { Energy value } \\
(\mathrm{kcal} / 100 \mathrm{ml})\end{array}$ \\
\hline F1 & $50 \%-46 \%-04 \%$ & 04 & $91 \pm 8$ & $\begin{array}{c}22.98 \pm \\
0.5\end{array}$ & $2.73 \pm 0.02$ & $91.92 \pm 1.3$ \\
\hline $\mathbf{F 2}$ & $\begin{array}{c}30 \%-28 \%-28 \%-4 \%- \\
5 \%-5 \%\end{array}$ & 04 & $95 \pm 6$ & $\begin{array}{c}25.24 \pm \\
1.12\end{array}$ & $15.25 \pm 0.2$ & $100.96 \pm 2.4$ \\
\hline F3 & $\begin{array}{c}27 \%-26 \%-26 \%-04 \%- \\
07 \%-5 \%-5 \%\end{array}$ & 07 & $110 \pm 5$ & $\begin{array}{c}30.09 \pm \\
0.8\end{array}$ & $15.32 \pm 0.3$ & $120.36 \pm 1.8$ \\
\hline
\end{tabular}


Table.5 Physicochemical properties and anti-nutritional factors of traditional and Fortified infant flours

\begin{tabular}{|c|c|c|c|c|c|c|c|c|}
\hline Flours & $\begin{array}{l}\text { Dry } \\
\text { matter } \\
(\%)\end{array}$ & Protein (\%) & Fat $(\%)$ & $\begin{array}{l}\text { Carbohydrates } \\
(\%)\end{array}$ & $\operatorname{Ash}(\%)$ & $\begin{array}{l}\text { Polyphenol } \\
\text { compounds } \\
\text { (mg } \\
\text { EAG/100g) }\end{array}$ & $\begin{array}{l}\text { Phytates } \\
\text { (mg/100g) }\end{array}$ & $\begin{array}{l}\text { Tannins } \\
(\mathrm{mg} / \mathbf{1 0 0 g})\end{array}$ \\
\hline \multicolumn{9}{|c|}{ Infant flours prepared by germination process } \\
\hline Fg1 & $96 \pm 1.2^{\mathrm{bc}}$ & $10.20 \pm 0.10^{\mathrm{b}}$ & $1.32 \pm 0.01^{\mathrm{b}}$ & $82.75 \pm 0.20^{\mathrm{d}}$ & $1.73 \pm 0.01^{\mathrm{b}}$ & $50.8 \pm 0.02^{\mathrm{d}}$ & $3.2 \pm 0.01^{\mathrm{a}}$ & $\begin{array}{l}25.40 \pm \\
0.01^{\mathrm{C}}\end{array}$ \\
\hline Fg2 & $\begin{array}{l}93.49 \pm \\
0.03^{\mathrm{b}}\end{array}$ & $\begin{array}{l}16.65 \pm \\
0.06^{\mathrm{d}}\end{array}$ & $\begin{array}{l}8.24 \pm \\
0.02^{\mathrm{e}}\end{array}$ & $65.53 \pm 0.12^{\mathrm{a}}$ & $\begin{array}{l}3.07 \pm \\
0.03^{\mathrm{d}}\end{array}$ & $\begin{array}{l}52.12 \pm \\
0.01^{\mathrm{e}}\end{array}$ & $3.3 \pm 0.01^{\mathrm{a}}$ & $\begin{array}{l}26.06 \pm \\
0.02^{\mathrm{d}}\end{array}$ \\
\hline Fg3 & $\begin{array}{l}96.85 \pm \\
0.02^{\mathrm{c}}\end{array}$ & $\begin{array}{l}16.65 \pm \\
0.06^{\mathrm{d}}\end{array}$ & $\begin{array}{l}8.27 \pm \\
0.03^{\mathrm{e}}\end{array}$ & $68.68 \pm 0.5^{\mathrm{b}}$ & $3.25 \pm 0.5^{\mathrm{e}}$ & $\begin{array}{l}53.54 \pm \\
0.02^{\mathrm{f}}\end{array}$ & $3.5 \pm 0.00^{\mathrm{a}}$ & $\begin{array}{l}26.77 \pm \\
0.06^{\mathrm{e}}\end{array}$ \\
\hline \multicolumn{9}{|c|}{ Infant flours prepared by fermentation process } \\
\hline F1 & $\begin{array}{l}94.25 \pm \\
0.04^{\mathrm{b}}\end{array}$ & $2.73 \pm 0.08^{\mathrm{a}}$ & $\begin{array}{l}0.72 \pm \\
0.06^{\mathrm{a}}\end{array}$ & $89.43 \pm 0.17^{\mathrm{e}}$ & $1.37 \pm 0.06^{\mathrm{a}}$ & $\begin{array}{l}48.36 \pm \\
0.04^{\mathrm{c}}\end{array}$ & $\begin{array}{l}5.32 \pm \\
0.02^{\mathrm{b}}\end{array}$ & $\begin{array}{l}24.18 \pm \\
0.08^{\mathrm{b}}\end{array}$ \\
\hline F2 & $\begin{array}{l}91,23 \pm \\
0.02^{\mathrm{a}}\end{array}$ & $\begin{array}{l}15.25 \pm \\
0.12^{\mathrm{c}}\end{array}$ & $5.8 \pm 0.1^{\mathrm{c}}$ & $67.40 \pm 0.13^{b}$ & $\begin{array}{l}2.78 \pm \\
0.12^{\mathrm{c}}\end{array}$ & $\begin{array}{l}46.06 \pm \\
0.03 \mathrm{a}\end{array}$ & $\begin{array}{l}5.34 \pm \\
0.03^{\mathrm{b}}\end{array}$ & $\begin{array}{l}23.91 \\
0.1^{\mathrm{b}}\end{array}$ \\
\hline $\mathbf{F 3}$ & $\begin{array}{l}92.62 \pm \\
0.03^{\mathrm{b}}\end{array}$ & $15.32 \pm 0.10^{\mathrm{c}}$ & $\begin{array}{l}6.2 \pm \\
0.01^{\mathrm{d}}\end{array}$ & $68.25 \pm 0.2^{\mathrm{c}}$ & $\begin{array}{l}2.85 \pm \\
0.08^{\mathrm{c}}\end{array}$ & $\begin{array}{l}47.82 \pm \\
0.05^{\mathrm{b}}\end{array}$ & $\begin{array}{l}5.33 \pm \\
0.02^{\mathrm{b}}\end{array}$ & $\begin{array}{l}23.03 \pm \\
0.02^{\mathrm{a}}\end{array}$ \\
\hline $\begin{array}{l}\text { Standard } \\
\text { infant } \\
\text { flour } \\
\text { FAO/OMS } \\
(2006)\end{array}$ & 95 & 15 & 8 & 68 & 2.9 & - & - & - \\
\hline
\end{tabular}

Values in the same row with different superscripts are significantly different $(\mathrm{p}<0.05)$.

Table.6 Functional properties and energy value of traditional and fortified infant flours

\begin{tabular}{|c|c|c|c|c|c|}
\hline & $\begin{array}{l}\text { Energy value } \\
\text { (kcal/ 100 g) }\end{array}$ & Solubility (\%) & Swelling (ge/g) & pH & $\begin{array}{c}\text { Titrable } \\
\text { acidity (\% eq } \\
\text { as lactic } \\
\text { acid) }\end{array}$ \\
\hline \multicolumn{6}{|c|}{ Infant flours prepared by germination process } \\
\hline Fg1 & $383.68 \pm 0.4^{\mathrm{ab}}$ & $58.52 \pm 0.14^{\mathrm{f}}$ & $9.43 \pm 0.11^{\mathrm{c}}$ & $6.12 \pm 0.04^{\mathrm{f}}$ & $0.13 \pm 0.05^{\mathrm{a}}$ \\
\hline Fg2 & $402.88 \pm 1.2^{\mathrm{c}}$ & $52.15 \pm 0.12^{\mathrm{e}}$ & $8.69 \pm 0.15^{\mathrm{b}}$ & $5.75 \pm 0.01^{\mathrm{e}}$ & $0.21 \pm 0.10^{\mathrm{b}}$ \\
\hline Fg3 & $415.75 \pm 2.61^{\mathrm{d}}$ & $46.49 \pm 0.21^{\mathrm{d}}$ & $6.03 \pm 0.12^{\mathrm{a}}$ & $5.65 \pm 0.02^{\mathrm{d}}$ & $0.26 \pm 0.01^{\mathrm{c}}$ \\
\hline \multicolumn{6}{|c|}{ Infant flours prepared by fermentation process } \\
\hline F1 & $375.12 \pm 0.60^{\mathrm{a}}$ & $16.95 \pm 0.46^{\mathrm{c}}$ & $14.08 \pm 0.18^{\mathrm{f}}$ & $3.75 \pm 0.01^{\mathrm{a}}$ & $2.45 \pm 0.1^{\mathrm{f}}$ \\
\hline F2 & $382.80 \pm 1.8^{\mathrm{a}}$ & $13.10 \pm 0.12^{b}$ & $13.18 \pm 0.33^{\mathrm{e}}$ & $4,05 \pm 0.03^{\mathrm{c}}$ & $1.75 \pm 0.05^{\mathrm{d}}$ \\
\hline F3 & $390.08 \pm 1.51^{\mathrm{b}}$ & $12.26 \pm 0.25^{\mathrm{a}}$ & $11.22 \pm 0.28^{\mathrm{d}}$ & $3.85 \pm 0.02^{b}$ & $2.32 \pm 0.25^{\mathrm{e}}$ \\
\hline $\begin{array}{l}\text { Standard infant } \\
\text { flour } \\
\text { FAO/OMS(2006) }\end{array}$ & 400 & - & - & - & - \\
\hline
\end{tabular}

Values in the same row with different superscripts are significantly different $(\mathrm{p}<0.05)$. 
Table.7 Mean count of organisms $\left(\log _{10} \mathrm{cfu} / \mathrm{g}\right)$ in infant flours Fg3 and F3

\begin{tabular}{c|cccc}
\hline Infant flours & Total aerobic & Yeast and molds & Faecal coliforms & Escherichia coli \\
\hline Fg3 & $2.40 \pm 0.16^{\mathrm{a}}$ & $2.00 \pm 0.14^{\mathrm{a}}$ & $0.00 \pm 0.00$ & $0.00 \pm 0.00$ \\
F3 & $3.95 \pm 0.21^{\mathrm{b}}$ & $2.75 \pm 0.10^{\mathrm{b}}$ & $0.00 \pm 0.00$ & $0.00 \pm 0.00$ \\
Standards & $<5$ & $<3$ & $<2$ & $<1$ \\
\hline
\end{tabular}

Values in the same row with different superscripts are significantly different $(\mathrm{p}<0.05)$.

Table.8 Mineral content of infant flours Fg3 and F3

\begin{tabular}{c|cccc}
\hline Infant flours & Iron & Calcium & Zinc & Magnesium \\
\hline Fg3 & $14.32 \pm 0.66^{\mathrm{b}}$ & $308.7 \pm 1.2^{\mathrm{b}}$ & $11.05 \pm 0.14^{\mathrm{b}}$ & $88.27 \pm 0.97^{\mathrm{b}}$ \\
F3 & $12.64 \pm 0.5^{\mathrm{a}}$ & $257.5 \pm 1.60^{\mathrm{a}}$ & $8.7 \pm 0.25^{\mathrm{a}}$ & $75.42 \pm 1.30^{\mathrm{a}}$ \\
Suitable composition & 8.5 & 341.2 & 3.7 & 48.7 \\
(mg/100g) FAO/OMS (2006) & & & & \\
\hline
\end{tabular}

Values in the same row with different superscripts are significantly different $(\mathrm{p}<0.05)$.

Fig.1 Photo of germinated red sorghum grains and maize

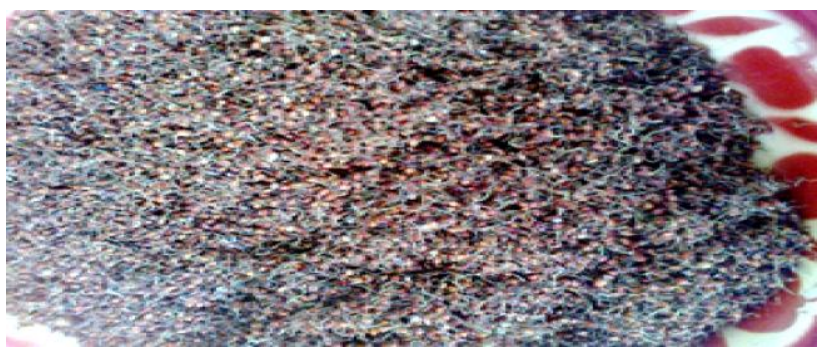

1a: Germinated red sorghum grains

Theincorporation of germinated maize flour and the addition of "Mawè', in fermented infant flour improved the nutritional and rheological characteristics of the porridge with a consistency of $110 \mathrm{~mm} / 30 \mathrm{sec}$, dry matter of $30.09 \%$ and an energy value of $120.36 \mathrm{kcal}$. These results were comparable with those of Elenga et al., (2012), which showed that the incorporation of malted maize flour and calcium carbonate into the fermented maize-groundnut allowed to prepare porridge with a recommended consistency of $120 \mathrm{~mm} / 30 \mathrm{sec}$ for a dry matter content of $30 \mathrm{~g}$ for $100 \mathrm{~g}$ of porridge. The result of Amoin et al., (2015) also showed that the use of germinated maize and sorghum, improved the dry matter and energy

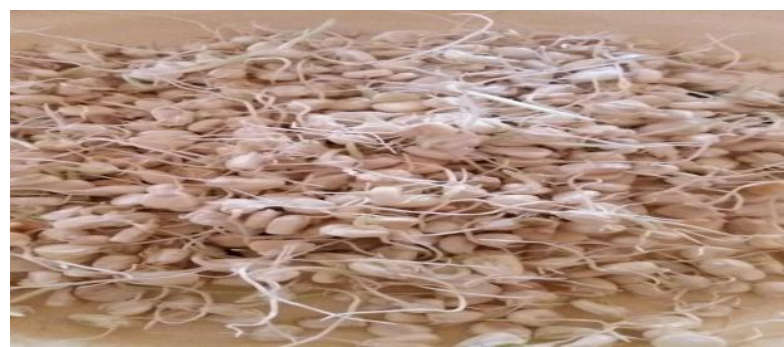

1b: Germinated maize grains

value of composite infant porridge. The germinated maize flour source of alpha amylases, hydrolytic enzymes capable of predigesting starch, prevents from swelling. Traoré et al., (2004) reported that in order to enhance energy value of gruel in order to meet nutritional requirements of young children, malted cereal flour should be added to infant flour in rate depending on raw material. These observations were in lined with those found by Kayodé et al., (2006) who reported that the malted maize flour is a good base in the preparation of infant gruel with good energy value. The incorporation of cereals with soybean increased the protein content in both $\mathrm{Fg} 3(16.65 \%)$ and $\mathrm{F} 3$ $(15.32 \%)$ fermented flour, which were higher 
than the recommended standard flour (15\%) FAO/WHO, (2006). These results are in lined with Onilude (2009) who showed that the protein content of the combined cereals and legumes combined was better than that produced from cereals alone. Moreover, germination and fermentation have considerably improved the protein content and digestibility of porridges. In fact, Amoin et al., (2015) have found protein contents of $15.80 \%$ and $15.25 \%$ respectively in germinated and fermented infant flours. Germinated infant Fg3 flour contains a lipid content $(8.27 \%)$, ash $(3.25 \%)$, and energy value $(415.75 \mathrm{kcal})$ in accordance with the FAO/WHO standard (2006) for complementary foods. However, the energy value $(390.08 \mathrm{kcal})$, lipid content $(6.2 \%)$, and ash $(2.85 \%)$ of the fermented infant flour was lower than those of standard flour $(8 \%)$ of lipids, ash (2.9\%), and $400 \mathrm{kcal}$ for energy value. This lower energy value of the fermented flour is explained by the use of carbohydrates as an energy source during the fermentation by microorganisms fermentable (Brou, 2000). This could mean that germination would improve nutritional value compare to fermentation (Syed et al., 2011; Sanoussi et al., 2013 and Amoin et al., 2015).This study is to firstly show the use of local available ingredient to improve the nutritional value of porridges such as the germination of local maize and sorghum, the use of sugar and "baobab" pulp to improve the dry matter, energy value, and ash content of porridges. On the other hand, the use of "Mawè" (dehulled and fermented maize dough), sugar, "baobab" pulp, and the incorporation of germinated maize flour has improved the energy value of fermented porridge.

Phenolic compounds and tannins (53.54 mg / $100 \mathrm{~g}$ and $26.77 \mathrm{mg} / 100 \mathrm{~g}$ ) of germinated infant flour $(\mathrm{Fg} 3)$ were significantly higher than those $(47.82 \mathrm{mg} / 100 \mathrm{~g}$ and $23.03 \mathrm{mg} /$
$100 \mathrm{~g})$ of the fermented infant flour (F3). The phytate content $(3.5 \mathrm{mg} / 100 \mathrm{~g})$ of $\mathrm{Fg} 3$ was lower than that of F3 $(5.33 \mathrm{mg} / 100 \mathrm{~g})$. This could mean that fermentation would reduce the levels of phenolic compounds and tannins in infant flours. Soro et al., (2013) had found respectively $105 \mathrm{mg} / 100 \mathrm{~g}$ of phenolic compounds in fermented yam flour incorporated with $30 \%$ of soybean flour. A rate of phenolic was between 51, 84 and 492, $86 \mathrm{mg} / 100 \mathrm{~g}$ in infant flours-based cereal, legumes and sugar producing of Burkina-Faso (Songré-Ouattara et al., 2016). It's appear that germination is likely to decrease the levels of phytates in infant flours. This result is in lined with that reported by Traoré et al., (2004) who showed that, during germination the degradation of phytates was due to the increase of phytasic activity. Kayodé et $a l$. ,(2012) showed that fermentation reduced polyphenol contents in fermented sorghum porridge $(2.12 \mathrm{mg} / \mathrm{g})$ compared to raw sorghum grains $(9.88 \mathrm{mg} / \mathrm{g})$. The results of our study revealed that the solubility indices and swelling of germinated, and fermented infant flours decreased from traditional to fortified formulations based on soybeans flour (from $26 \%$ to $31 \%$ ). These results were close to those found by Soro et al., (2013), which showed that, with the exception of $10 \%$ of soybean flour fortified, the swelling and the solubility of yam flour decrease with the rate of the incorporation of soybeans. According to our results, germinated flour $\mathrm{Fg} 3(46.49 \%$ \pm 0.21) was about four (04) times more soluble than fermented flour F3 (12.26\% \pm 0.25). In addition, Soro et al., (2013) have found $11.06 \%$ as solubility and 6.07 ge/gas swelling in fermented yam flours fortified with $30 \%$ of soybean flour. The germinated flour Fg3 (6.03 ge / $g \pm 0.12)$ has a lower ( $\mathrm{p}<$ $0.05 \%$ ) swelling power than that of fermented flour F3 (11.22 ge / $\mathrm{g} \pm 0.28$ ). The high solubility of the germinated flour $\mathrm{Fg} 3$ was due to the concentration of germinated maize and sorghum flour, source of alpha amylases, 
hydrolytic enzymes capable of pre-digesting the starch which prevent swelling. The conversion of insoluble starch to soluble sugars allows a reduction in viscosity and has an effect on the decrease of porridges consistency for children who can consume small volume of porridges, while consuming a large quantity of dry matter (Anigo et al., 2010; Zannou et al., 2011; Amoin et al., 2015). The addition of germinated maize flour allowed a sufficient fluid porridges preparation with high dry matter and high energy value. Moreover, a high correlation $\left(r^{2}\right.$ $=0.82$ ) was found between the swelling and the solubility indices (Soro et al., 2013).

The results of microbiological analysis obtained (Table 7), showed that all the infants flours produced were conformed to the complementary food microbiological standard (FAO/OMS, 1994). It was observed that the fermented infant flour has a slight degradation of their microbiological qualities (increase of total aerobic, yeast and moulds numbers) although they remain conform to the standard.Iron, calcium, zinc, and magnesium levels were higher in germinated infant flour (Fg3) than in fermented infant flour (F3) (Table 8).This study is to firstly show, the use of local germinated maize and sorghum and baobab pulp which has improved the bioavailability of minerals in germinated infant flours. This could mean that germination processes are likely to improve bioavailability of minerals $b$ etter than fermentation (Syed et al., 2011; Sanoussi et al., 2013 and Amoin et al., 2015).This is due to the fact that germination is likely to increase the $r$ etention of minerals (Helland et al., 2002;Traoré et al., 2004).This bioavailability of minerals in germinated infant flours was due to the ability of the germination technique to reduce phytate levels in infant flours (Traoré et al., 2004; Kayodé et al., 2006). Anigo et al., (2010) have found iron, magnesium, calcium, and zinc in germinated maize and sorghum flours enriched with groundnut and soybean, respectively of $23.98 \mathrm{mg}, 148.91 \mathrm{mg}, 47.66 \mathrm{mg}$ and $7.88 \mathrm{mg}$. The levels of $12.58 \mathrm{mg}$, $74.30 \mathrm{mg}, 268.50 \mathrm{mg}$ and $7.50 \mathrm{mg}$ respectively for iron, magnesium, calcium, and zinc were found by (Amoin et al., 2015) in germinated maize and sorghum infant flours fortified with soybeans flour. The presence of these minerals in infant flours is beneficial because they are ability to improve child growth. It is also essential for a large number of metabolic reactions (Lokombé et al., 2004). Calcium provides bone stiffness and child growth (Weaver et al., 2007). Zinc represents with iron one of the most concentrated minerals in the brain. Zinc is also implicated in immunity as it reduces the incidence and severity of diarrhea in children (Amoussa Hounkpatin, 2011). Magnesium is needed for biochemical reactions in the body to maintain muscle, improve nerve function, maintain heart rhythm, and regulate blood sugar levels (Weaver et al., 2007). Traditional methods such as germination and fermentation are likely to improve the quality of foods in nutrients. These results are in phasewith those found by Brou (2000), Sanoussi et al., (2013) and Amoin et al., (2015).

This study contributes to the improvement of complementary food characteristics by formulating adequate infant flours using germination and fermentation of local available raw material. Germinated infant flour (Fg3) and fermented infant flour (F3) have been used here. These two infant flours contain good protein, fat, carbohydrate, mineral, and energy value, conforms to FAO/WHO (2006) recommendations. The nutritional value of germinated infant flour is higher than the one in fermented infant flour. The germination process is likely to improve the quality of the flour compare to fermentation. This study is to firstly focus on the germination of maize and sorghum, the 
use of sugar, and "baobab" pulp which could improve the energy value of porridges and the bioavailability of minerals in germinated infant flours. On the other hand, the use of "Mawè" (dehulled and fermented maize dough), sugar, "baobab" pulp, and the incorporation of germinated maize flour could help in the improvement of the energy value and the consistency of fermented porridge, while increasing the potential to overcome protein-energy malnutrition and mineral deficiencies within infants and young children. In perspective, we plan to evaluate the biological efficacy of germinated and fermented infant flours in order to assess the quality of flour in vivo.

\section{Acknowledgements}

The study was sponsored by the Government of Benin. We are grateful to the researchers' inthe laboratory of study and research in enzymatic and food engineering of Polytechnic School of Abomey-Calaviand the Laboratory of Human Nutritionof the Faculty of Agronomics Sciences, University of Abomey-Calavi.

\section{References}

Amoin, K.K.A., E.A. Agbo, A.G. Dago, A.G. Gbogouri, D.K. Brou and Dago, G. 2015. Comparaison des caractéristiques nutritionnelles et rhéologiques des bouillies infantiles préparées par les techniques de germination et de fermentation. International Journal of Biological and Chemical Sciences, 9(2): 944-953.

AmoussaHounkpatin, W., 2011. Evaluation $\mathrm{du}$ potentiel de couverture des besoins en vitamines A des jeunes enfants à partir des sauces accompagnant les aliments de base consommés au Bénin. Thèse de Doctorat de l'Université Montpellier 2. p 1-109.
Anigo, K.M., D.A. Ameh, S. Ibrahim and Danbauchi, S.S. 2010. Nutrient composition of complementary food gruels formulated from malted cereals, soybeans and groundnut for use in North-western Nigeria. African Journal of Food Science, 65-72.

Ategbo, E.A., 1993. Food and nutrition insecurity in northern Benin: impact on growth performance of children and on year to year nutritional status of adults. $\mathrm{PhD}$ Thesis Wageningen university, $\mathrm{N}$ etherlands. p 1-150.

Brou, K., 2000. La cofermentation comme stratégie pour l'amélioration de la valeur nutritionnelle des aliments de complément dans les pays en développement. Thèse de doctorat 3emè cycle. Université de Cocody (Côte d'Ivoire), p.126.

Dolan, C., M. Mwangome and Khara, T. 2015. Extent of stunting and wasting in the same children. Panel in global nutrition report 2015: Actions and accountability to advance nutrition and sustainable development. International Food Policy Research Institute: 102108.

Elenga, M., 2012. Amélioration de la qualité nutritionnelle et de la densité énergétique des bouilles de maïs fermenté et de la farine d'igname utilisée comme aliment de complément $\mathrm{du}$ nourrisson. Thèse de Doctorat de l'Université de Marien Ngouabi, 104p.

FAO/OMS., 2006. Programme mixte FAO/OMS sur les normes alimentaires. Rapport des vingt-septièmes sessions du comité du codex sur la nutrition et les aliments diététiques ou de régime. Alinom 06/29/26, 105 p.

Global Nutrition Report (GNR) Partners., 2016. Global nutrition report from promise to impact ending malnutrition by 2030 . p 7-20

Helland, M.H., and Wickland T. 2002. Eff et 
de temps de germination sur l'alpha amylase et la viscosité de la bouillie de maïs. Res Alimentaire Int., 35: 315-321.

Hounhouigan, D.J., M.J.R. Nout, C.M. Nago, J.H. Houben and Rombouts, F.M. 1993. Changes is the physico-chemical properties of maize during natural fermentation of mawè. Journal of cereal science 17: 291-300.

INSAE., 2015. Enquête par grappes à indicateurs multiples (MICS): rapport de résultats clés-Bénin. p 4-15.

Kayodé, A.P.P., D.J. Hounhouigan, M.J.R. Nout and Niehof, A. 2006. Household production of sorghum beer in Benin: technological and socio-economic aspects. International Journal of Consumer Studies 1470-6431.

Kayodé, A.P.P., F.U.G. Akogou, W. AmoussaHounkpatin and Hounhouigan, D. J. 2012. Eff ets des procédés de transformation sur la valeur nutritionnelle des formulations de bouillies de complément à base de sorgho.Int. J. Biol. Chem. Sci. 6(5): 2192-2201.

Kouton, S.E., W. AmoussaHounkpatin, V.Y. Ballogou, J.H. Lokonon and Soumanou, M.M. 2017.Caractérisation de l'alimentation des jeunes enfants âgés de 6 à 36 mois en milieu rural et urbain du Sud -Bénin. Journal of Applied Biosciences. 110: 10831-10840.

Lokombé-Léké A., and Mullié, C. 2004. Nutrition du nourrisson et diversification alimentaire. Cahiers de Nutrition et Diététique, 39: 349-359.

Onilude, A.A., 2009. Microbiological and chemical changes during production of malted and fermented Cereal- legume weaning foods. Advances in Food Sciences, 31(3):139-145.

Ponka, R., E.L.T. Nankap, S.T. Tambe and Fokou, E. 2016.Composition nutritionnelle de quelques farines infantiles artisanales du Cameroun.
International Journal of Innovation and Applied Studies. 280-292.

Salle, B., 2009. Alimentation du nouveau-né et du nourrisson. Rapport 24 Février 2009. Tome 193, No 2, p 431-446.

Sanoussi, A., A. Dansi, I. Bokossa-Yaou, M. Dansi, M. Egounl ety, L. O. Sanni and Sanni, A. 2013.Formulation and biochemical characterization of swe et potato (Ipomoea batatas) based infant flours fortified with soybean and sorghum flours.Int.J.Curr.Microbiol.App.Sci, 2(7): 22-34.

Songré-Ouattara, L.T., K. Gorga, A. Savadogo, F. Bationo and Diawara, B. 2016. Evaluation de l'aptitude nutritionnelle des aliments utilisés dans l'alimentation complémentaire du jeune enfant au Burkina Faso. J. Soc. OuestAfr. Chimie, 041: 41- 50.

Soro, S., G. Konan, E. Elleingand, D. N'guessanand Koffi, E. 2013. Formulation d'aliments infantiles à base de farines d'igname enrichies au soja. African Journal of Food, Agriculture, Nutrition and Development, 13(5): 8313-8339.

Syed, A.S., Z. Aurang, M. Tariq, N. Nadia, S. Muhammad, A. Abdul and Asim, M. 2011. Eff ets de la germination sur la qualité nutritionnelle des variétés de haricot mungo. Revue Africaine de la Recherche Agricole, 6(22): 5091-5098.

Traoré, C., C. Mouqu et, C. Icard-vreniere, A. Traoré and Trèche, S. 2004. Change in nutrient composition, phytate and cyanide content and -amylase activity during cereal malting in small production unit in Ouagadougou (Burkina Faso). Food. Chem. 88: 105114.

Trèche, S., 2002. Complementary foods in developing countries: importance, required characteristics, constraints and potential strategies for improvement. In 
Kolsteren P, Hoerée T, Perez-Cu etoeds: Proceedings of the International Colloquium promoting growth and development of under-fives. Antwerpen: ITG Press: 132-148.

Tshite, F.N., V.T. Mulamba and Ndianabo, M.J.T. 2015.Mise au point d'une farine précuite à base de maïs (Zeamays) ET de soja (Glycine max) par la méthode traditionnelle. Int. J. Biol. Chem. Sci. 9(6): 2608-2622.

Umaru, H.A., R. Adamu, D. Dahiru and Nadro, M.S. 2007. Levels of antinutritional factors in some wild edible fruits of Northern Nigeria. African Journal of Biotechnology, 6(16): 1935-1938.

Victora, C.G., R. Bahl, A.J. Barros, G.V. Franca, S. Horton, J. Krasevec, S. Murch, M.J. Sankar, N. Walker and Rollins, N.C. 2016. Breastfeeding in the 21s Century: Epidemiology, Mechanisms, and Lifelong Effect. Lancet 387 (10017): 475-490.

Vieira-Dalodé, G., L. Jerpersen, J. Hounhouigan, P.L. Moller, C.M. Nago and Jakobsen, M. 2007. Lactic acid basteria and yeasts associated with gowe production from sorghum in Benin. Journal of Applied Microbiology 103: 342-349.

Weaver C.M., and Mobley, S.L. 2007. Calcium intake, body fat, and bones a complex relation. Am. J. Clin. Nutr., 86(3):527.

WHO, 2003. Alimentation complémentaire des jeunes enfants dans les pays en développement. OMS: Genève; 130131.

WHO, 2012. Maternel infant and young child nutrition: Draft comprehensive implementation plan. 'Geneva. http://apps.who.int/gb/ebwha/pdf_files.

Zannou-Tchoko, V.J., L. B. Ahui-bitty, K. Kouame, K.G.M. Bouaffou and Dally, T. 2011.Utilisation de la farine de maïs germe source d'alpha amylases pour augmenter la densité énergétique de bouillies de sevrage à base de manioc et son dérivé, l'attiéké.Journal of Applied Biosciences 37: 2477 - 2484.

\section{How to cite this article:}

Sandrine E. Kouton, Waliou Amoussa-Hounkpatin, Venerande Y. Ballogou and Mohamed M. Soumanou. 2017. Nutritional, Microbiological and Rheological Characteristics of Porridges Prepared from Infant Flours Based on Germinated and Fermented Cereals Fortified with Soybean. Int.J.Curr.Microbiol.App.Sci. 6(10): 4838-4852. doi: https://doi.org/10.20546/ijcmas.2017.610.452 